\title{
Abraham, høflighedens ridder ${ }^{2}$
}

\section{Professor, dr.theol. Hans J. Lundager Jensen}

Abstract: In the Hebrew Bible, the do-ut-des-relationship, so often used to describe the exchange between the divine and the human realms, designates the exchange between human partners. Professional exchange, by contrast, has a problematic status in the Hebrew Bible with its wellknown negative views on trade, traders, and their wealth. Yet in this article, "Abraham, knight of courtesy", I argue that Abraham in Genesis is presented as a person of great wealth with frequent contacts across sis is and ethnical borders and with great skills for negotiations. His commit ment to family and family religion does not rule out frequent contacts with persons from other cultures and religions. Some of the Abraham harratives may therefore have been written also as a tacit critique of more dominating, and more exclusive, theological currents in the $\mathrm{He}$ brew Bible.

Key words: Abraham - merchants' religion - Old Testament Theology gift - exchange - sacrifice - Book of Genesis.

\section{Hvorfor Abraham?}

Mange af de bedst kendte personligheder fra Det Gamle Testamente virker, som om de tjener som typer for bestemte sociale roller eller funktioner: Jakob er den snu underdog og hans søn Josef den milde og vise administrator. Moses er den store folkefører, der forener profetiske, magiske, kongelige og præstelige evner og funktioner. Tilsvarende typer kan formodes, hvad angår Elias (shaman-lignende magiker), Jeremias (budbringer-profet), David (krigerisk konge), Salomo (vis bygmester). Er også Abraham en type, og i givet fald hvilken? Et umiddelbart svar vil sikkert være, at i Abraham materialiserer sig særligt vægtige, teologiske temaer: Israels ældste stamfader, den første udvalgte, pagtens herre, den lydige og tavse, tros-tillidens ridder. Det kan man måske kalde en 'teologisk' Abraham. Hvis Abraham snarere

1. Artiklen bygger på mit oplæg "Abraham, pagt, handel" ved seminaret ved Det Teologiske Fakultet, Aarhus Universitet d. 16. sept. 2010, "Pagt og udveksling". Artiklen dedikeres hermed Ole Davidsen, mangeårig ven og kollega. 
associerer i retning af kameler, telte og nomadisk gæstfrihed under Mamres ege, kan man tilsvarende tale om en 'bibelhistorisk' Abraham. Begge svar er velfunderede i Genesis. Men de udgør ikke alt, hvad der siges om Abraham i Genesis. Jeg vil i det følgende se bort fra den 'bibelhistoriske' Abraham og indledningsvis mest forholde mig til den 'teologiske'.

De temaer, pagt og udveksling, som særligt forbindes med Abraham, er afgørende ikke kun for teologien, men også for antropologien. Og netop pagt og udveksling med både deres teologiske og deres antropologiske dimensioner har stået centralt i Ole Davidsens forskning, som det ses både i disputatsen The Narrative Jesus ${ }^{2}$ og i artikler. ${ }^{3}$ Den semiotiske tradition, som Ole Davidsen har trukket på, blev i 1960 'erne udviklet navnlig af miljøet omkring A.J. Greimas i Paris tæt kontakt med samtidens antropologi. ${ }^{4}$ Med sin forkærlighed for formaliseringer og skematiseringer kan Davidsens tilgang tage sig eksotisk ud i forhold til normale eksegetiske og teologiske argumentationer. Men hans problemstillinger er teologisk klassiske, nærmest paulinske, for de angår forholdet mellem guddommelig gave og fordring på den ene side og menneskelige svar på den anden. Tekstgrundlaget i Genesis for denne 'paulinske' Abraham er primært de tekster, som også Davidsen særlig har interesseret sig for: Gen 17 om pagten og omskærelsen, Gen 18 om Isaks fødsel, Gen 22 om den ikke-realiserede ofring af Isak, ved siden af Gen 15 med dens ejendommelige pagtsceremoni og det prægnante udsagn om Abrahams tro.

Den antropologiske og filosofiske diskussion af udveksling har baseret sig på Marcel Mauss' skrift om gaven fra 1925, Essai sur le don. ${ }^{5}$

2. Ole Davidsen, The Narrative Jesus (Århus: Aarhus Universitetsforlag 1993), fx p. 119. 251, n. 22.

3. Ole Davidsen, "Og Gud sagde til Abraham", RvT 27 (1995), 79-118; jf. den tidlige artikel, "Bund. Ein religionssemiotischer Beitrag zur Definition der alttestamentlichen Bundesstruktur", Linguistica Biblica, 48 (1980), 49-96; og jf. den semiotiske selvbiografi i: Danske tegn. Dansk betydningsforskning presenteret korte intellektuelle biografier, red. Torkild Thellefsen, Bent Sørensen \& Peer Bundgaard (København: Forlaget Semiosis 2010), 59-63.

4. Jf. Algirdas Julien Greimas \& Joseph Courtès, Semiotik. Sprogteoretisk ordbog dansk redaktion: Per Aage Brandt \& Ole Davidsen (Århus: Aarhus Universitetsforlag 1988).

5. Marcel Mauss, "Essai sur le don. Forme et raison de l'échange dans les sociétés archaiques", L'Année Sociologique 1923-24.
Den er gået over bl.a. Georges Bataille ${ }^{6}$ og Jacques Derrida ${ }^{7}$. Med John Milbanks bidrag 8 er en oprindelig teologisk problemstilling nået hjem igen efter en antropologisk udlændighed og har udfordret også Lutherforskningen.?

\section{Guddommelig gave, guddommelig økonomi}

Også i en snævrere gammeltestamentlig sammenhæng kan man med fordel anlægge et gavegivningsaspekt på forholdet mellem det guddommelige og det menneskelige. Som bekendt er forholdet mellem Jahve og Israel, hhv. en forløber som netop Abraham, i visse tekster terminologisk benævnt $b^{e}$ rît, traditionelt på dansk 'pagt'. Og man har i forestillingen om 'pagtstanken' kunnet se det essentielt gammeltestamentlige, Det Gamle Testamentes teologiske tyngde- og omdrejningspunkt. ${ }^{10}$ Samtidig har der dannet sig konsensus om at se de deuteronomistiske pagtsbegreb som en teologisk transponering af et generelt nærorientalsk, storpolitisk begreb om et kontraktuelt forhold mellem vasalherre og vasaller. ${ }^{11}$ I sin struktur, med vasalherrens opstilling af kontraktens indhold og betingelserne for overholdelse og brud, kan pagtstanken antages at have været almindeligt udbredt bronze- og jernalder. I de former, hvori den foreligger i deuteronomistiske tekster i Det Gamle Testamente, er den formentlig inspireret af nyassyriske edstraktater mellem den assyriske storkonge og han vasaller, hvis form er veldokumenteret fra Assurhaddons regeringstid.

6. Georges Bataille, La part maudite (Paris: Les Éditions de minuit 1967) (først udgivet i 1949): der gives en særlig slags økonomi, hvor værdier destrueres, som ren luksus eller i ren destruktivitet. Denne 'generelle økonomi' har et kosmisk udgangspunkt og et arkaisk symbol i solen, der udstråler energi i ren (heldigvis langsom) selvødelæggelse.

7. Jacques Derrida, bl.a. Donner le temps. 1. La fausse monnaie (Paris: Galilée 1991) gaven kan egentlig ikke gives, for hvis en giver ved, at han giver en gave, er den allerede blevet til økonomi.

8. John Milbank, "Can a Gift Be Given? Prolegomena to a Future Trinitarian Metaphysic", Modern Theology 11 (1995), 119-161; "Fictioning Things: Gift and Narrative", Religion and Literature 37 (3), 1-37.

9. Bo Kristian Holm, "Justification and reciprocity. 'Purified gift-exchange' in Luther and Milbank", Word - Gift - Being. Justification - Economy - Ontology red. Bo Kristian Holm \& Peter Widmann (Tübingen: Mohr Siebeck 2009), 87 116

10. Klassisk Walter Eichrodt, Theologie des Alten Testaments 1-3 (Leipzig: Hinrichs 1933-1939).

11. God sammenfatning af forskningen, også af det nærorientalske materiale, George E. Mendenhall \& Gary A. Herion, "Covenant", Anchor Bible Dictionary I (New York: Doubleday 1992), 1179-1202. 
Det danske ord 'pagt' som gengivelse af $b^{e}$ rît er fortsat dækkende, hvis det lidt ukurante ord forstås som synonymt med 'kontrakt' elle 'aftale'.12

Tilskyndelsen til i fænomenet 'pagt' at se en art centrum eller essens af gammeltestamentlig teologi er dog i forskningen blevet modereret af, at $b^{e}$ rît ikke forekommer bredt i Det Gamle Testamente, men er karakteristisk for navnlig én bestemt teologisk retning, deuteronomismen. Begrebet kan præge efter-deuteronomistiske tekster som de præsteskriftlige tekster i Genesis, herunder Gen 17, hvor det har fået en drejning bort fra det kontraktuelle i retning af et generøst og ubetinget guddommeligt tilsagn. Derimod skulle begrebet $b^{e}$ rît ikke kunne bruges til at karakterisere ældre lag i gammeltestamentlig Jahve-tænkning. Men man kan ikke deraf slutte, at kontrakttænkning som sådan skulle være irrelevant for andre, også tidligere, teologiske strømninger i Det Gamle Testamente. Kontrakttænkning har tværtimod hørt til, hvad Morton Smith har kaldt den Nære Orients "common theology".13 Det særlige ved den deuteronomistiske 'pagts'-tænkning er derfor dels, at forholdet tematiseres eksplicit, dels, at dette er ment som et polemisk alternativ til storpolitiske kontrakter. Og i det omfang, man ønsker at basere en gammeltestamentlig teologi på pagtsbegrebet, må det ske med bevidsthed om, at dette begreb er et nærorientalsk theologoumenon. ${ }^{14}$

For Morton Smith var do-ut-des en uproblematisk karakteristik af en central dimension i nærorientalske teologi. Men do-ut-des-formlen kan være misvisende ved at invitere til at forstå forholdet som et bytte af goder og / eller tjenester, der initieres af en menneskelig part (do) med det formål at udvirke, at en guddommelige part giver en genydelse (des), og at de to parters ydelser er symmetriske i betydningen ækvivalente. Begge disse forudsætninger er uholdbare. Dels er de to parters 'gaver' omvendt proportionale. Det udtrykkes eksemplarisk slagt- eller måltidsofferet, hvor de to ydelser forholder sig som offerdyret i sin helhed til dets nyrer, 'leverlap' og indvoldsfedt. Dels er udvekslingen asymmetrisk, hvad rækkefølgen angår. For hvis offerdyr kommer fra guddommen, kan der ikke ofres, med mindre guddom-

12. Jf. Den nye aftale (København: Bibelselskabets forlag 2007).

13. Jf. Morton Smith, "The Common Theology of the Ancient Near East", Journal of Biblical Literature 71 (1952), 135-147; p. 145: "the relation between people and god was therefore always a contractual one, and the question as to when it was first given dramatic expression in a formal contract is one for the history rather of rhetoric than of theology". 'Nærorientalsk' her underforstår ikke, at kontrakttænkningen skulle have været unikt for denne region.

14. De fleste eksplicitte 'teologiske' udsagn i Det Gamle Testamente angår ikke, hvad guddommen er (i forhold til det jordiske), men bvem guddommen er (blandt alternativer). men allerede har givet. Derfor bringer Kain og Abel i de første ofringer, der berettes om i Det Gamle Testamente, ikke deres gaver af korn og småkvæg for at opnå stor høst og meget kvæg (Gen 4); de kan kun give Jahve gaver, fordi han allerede har givet. ${ }^{15}$ Det er altså relevant nok at forstå forholdet mellem guddom og menneske som et kontraktuelt forhold og dermed en slags økonomi, hvor begge parter giver til og modtager fra hinanden. Men det er en særlig guddommelig økonomi, hvor den ene part altid giver først og mest, og den. anden part altid giver sidst og mindst. ${ }^{16}$

Den menneskelige økonomi: Tyrus, Salomo, Tobit, Buddenbrooks

Do-ut-des beskriver derimod udmærket den menneskelige økonomi, ikke mindst den handel, der foregik i den nærorientalske verden. Fra den tidlige bronzealder af blev der fragtet og handlet varer over lange afstande, selv om det mest drejede sig om luksusvarer for eliterne ( $\mathrm{fx}_{\mathrm{x}}$ klassiske fønikiske fremstillings- og handelsvarer som purpurklæde, bronzegenstande, elfenbensarbejder ${ }^{17}$ ). Størstedelen af konsumprodukter blev uden tvivl blev fremstillet i selvberoende husholdninger eller handlet lokalt. ${ }^{18}$ Også her vil man kunne se et do-ut-desforhold; men det er handel i den førstnævnte forstand, der er relevant i forbindelse med Abraham.

Mens visse sociale gruppers og/eller situationers typiske religiøse prioriteter, $\mathrm{fx}$ de der har været relevante for familier, for agerbrugere i landsbyer, for skrivere i byer eller for kultpersonale i templer, er mere eller mindre velkendte fra Det Gamle Testamente, er andre gruppers

15. Det udelukker ikke, at den menneskelige parts gengave også kan gives med det formål igen at modtage. Nutidige teologiske forbehold heroverfor vil skulle medtænke, at den nærorientalske verden af gode grunde (nemlig i betragtning af, at hungersnød, plyndring og naturkatastrofer var realistiske muligheder) havde svært ved at se forskel på besiddelse og velsignelse.

16. I min artikel "Subsolar teligionsapologi", i: Interesse for Gud. Ni tidssvarende essay, red. Niels Grønkjær \& Henrik Brandt Petersen (Frederiksberg: Anis 2002), 8489 har jeg foreslået i den guddommelige økonomi at se et eksempel på Batailles 'generelle økonomi'. Slet så generøse som solen var de nærorientalske guddomme måske ikke. Men det er dog næppe tilfældigt, at solen, et yndet gudsbillede i Den Nære Orient ogsa kunne anvendes for Jahve: if bla Mark S. Smith, The Early History of God (Grand Rapids, Eerdmans 2002), 148-159.

17. Mario Liverani, Antico Oriente. Storia societè economia (Rom: Laterza 1999), 698. Jf. listen over produkter i Ez 27,12-24.

18. Kurt Galling, "Handel und Verkehr", Biblisches Reallexikon, 2. ed., (Tübingen: Mohr 1977), 134-138; Daniel C. Snell, "Trade and Commerce (ANE)", Anchor Bible Dictionary VI, 625-629: 625. 
det langt mindre. Det gælder således for handlendes. ${ }^{19}$ Det skyldes sikkert ikke mindst, at det umiddelbare indtryk af handel i Det Gamle Testamente er temmelig negativt (således Am 8,5-6; Hos 12,89). ${ }^{20}$ Ekstreme, men sikkert ganske betegnende for en udbredt opfattelse, er Ezekiels (retorisk storladne) skadefro tirader imod handelsbyen par excellence, det fønikiske Tyrus (Ez 26-28). Der er en decideret fjendtlighed imod privat luksusforbrug i Ezekiels Bog (muligvis ford rigdomme rettelig burde gå til templet, if. præsten Ezekiel?), som det ses i fordømmelserne af Jerusalem som prostitueret i kap. 16 (v. 29 'kræmmerlandet Kaldæa', 'eres $\left.k^{e} n a^{\prime} a n\right)$ og 23 (v. 41: "min [dvs. Jahves] røgelse og min olie").

Omvendt er handelen i princippet beskrevet positivt i forbindelse med Salomo (1 Kong 10). ${ }^{21}$ Han skal bl.a. have været stor i international handel med heste og vogne, der blev indkøbt i Egypten og solgt videre nordpå til aramæiske og hittitiske fyrster. Salomo er i stadig kontakt med Tyrus. Uden fønikisk tømmer og know-how, betalt med landbrugsprodukter, var det salomoniske tempel ikke blevet bygget (1 Kong 5,15-32). Forholdet mellem Salomo og Tyrus konge, Hiram, beskrives som et forhold mellem ligestillede. Der hersker fred (shalôm) imellem dem; de har sluttet en 'pagt' ( $\left.b^{e} r_{i \hat{t}}\right)$; og hele Salomos foretagsomhed er funderet i den visdom (chåkmah), som Jahve har givet ham (1 Kong 5,26).22

Den positive beskrivelse af Salomo og den negative af Tyrus er i øvrigt enige om at forbinde international handel med stor rigdom, og dermed, i sagens natur, med risiko for moralsk fordxrv. Og Salomofortællingernes velvillige billede af international handel skal tydeligvis også forstås som en mytisk-legendarisk guldalder. Dette billede har sin plads i en bestemmelse af en særlig handelsmentalitet, hvis en sådan har eksisteret; men der mangler også en mere realistisk, hverdags-

19. Gode fremstillinger som Erhard S. Gerstenberger, Theologien im Alten Testament Pluralität und Synkretismus alttestamentlicher Gottesglauben (Stuttgart: Kohlhammer 2001) eller Religious Diversity in Ancient Israel and Judah, red. Francesca Stavrakopoulou \& John Barton (London: T. \& T. Clark 2010) har ikke særlige afsnit om købmænds religion eller religiøsitet.

20. Geert Hallbäck, "Købmand”, Gads Bibelleksikon (København: Gad 1998), 453 Snell (1992), 628-629; Ernst Axel Knauf, Die Umwelt des Alten Testaments, Neuer Stuttgarter Kommentar Altes Testament (Stuttgart: Verlag Katholisches Bibelwerk 1994), 44-45.

21. Det er først den redaktionelle, deuteronomiserende ramme (1 Kong 11), der kaster et negativt lys over Salomos internationale kontakter.

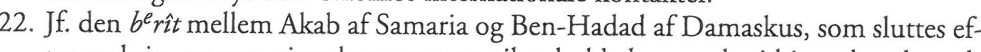
ter en krig, og som giver kongerne ret til at holde basargader i hinandens hovedstæder (1 Kong 20,34). agtig komponent. Hvordan har tankegangen været hos folk, der har været engageret med handel på et mindre guldalderagtigt niveau?

En første fornemmelse af, at det kunne være værd at undersøge et muligt aspekt 'købmænds religiøsitet' lidt nærmere, kan man få ved aspekter af Tobits Bog. For selv om det er interessant nok, at Tobit er en særdeles from israelit med en udstrakt social-etnisk pligtfølelse, ${ }^{23}$ så kan man også hxfte sig ved, at Tobits arbejde ifølge fortællingen bestod i at opkøbe varer i Medien til brug for det assyriske hofs husholdning (Tob 1,14). Den funktion indebar vidtløftig rejseaktivitet og indsigt i sofistikerede pengetransaktioner - funktioner og kvalifikationer han giver videre til sin søn Tobias, og som denne får god brug for, som det viser sig senere i historien. ${ }^{24} \mathrm{Her}$ kan man finde lidt af den ånd, som fik et mere berømt litterære nedslag i Thomas Manns Huset.Buddenbrook. Det er langt fra den eneste roman i den realistiske tradition, der lægger stor vægt på omgangen med penge; men den er særlig ved at give en sympatetisk skildring af grossister og deres familie, dvs. af et handelsaristokrati. Faktisk er Buddenbrooks nogenlunde samtidig med Émile Durkheims forelæsninger over sociale grupper og deres distinkte moralkonstellationer, der er samlet Leçons de sociologie, ${ }^{25}$ og romanen er i sig selv, som alle gode realistiske romaner, et plausibelt bud på en social-mental diagnose af en bestemt samfundsgruppe.

I denne sammenhæng er Abraham måske ikke et umiddelbart lovende sted at finde belæring. Blandt alle gammeltestamentlige helte hører han formentlig til de bedst undersøgte, de hyppigst omtalte, og der er næppe nogen mulig og ikke mindst umulig (bl.a. arkæologisk) sten, der ikke allerede er vendt, sådan at en del nyere forskning snarest har bestræbt sig på at demontere usikker viden, frem for at fremkalde ny. ${ }^{26}$ På den anden side er det netop en af udfordringerne ved

23. Når han selv skal sige det: Tobit 1,3: "Jeg, Tobit, har fulgt sandheds og retfærdig heds veje hele mit liv og gjort mange velgerninger mod mine brødre og landsmeds veje hele

24. Hans J. Lundager Jensen, "Tobit og Judit", Det brede og det skarpe. Religionsvidenskabelige studier, red. Armin W. Geertz, Hans J. Lundager Jensen \& Jens Pete Schjødt (København: Anis 2004), 151-165.

25. Émile Durkeim, Leçons de sociologie (Paris: Presses Universitaires de France 1950); med 'sociologi' menes her egentlig en social- eller gruppepsykologi (Georges Davy, "Introduction", ibid., 13) eller, måske i vore dage bedre, gruppementalitet, altså beskrivelsen af, hvilke værdier og moralske prioriteter, der typisk dominerer hos medlemmer af en gruppe, fx en stand eller et erhverv.

26. A.R. Millards artikel "Abraham", Anchor Bible Dictionary I, 35-41 er markant reaktionær i sit forsvar for en historisk, mellembronzealderlig historisk oprindelse til overleveringen om Abraham, men indeholder til gengæld et godt og koncist 
at have bibelsk eksegese som metier: At skulle nylæse velkendte, undertiden alt for velkendte, tekster.

\section{Gensyn med Abraham}

Abraham ligner andre Genesis-helte på mindst ét punkt: I forhold til den vægt, de tillægges i Genesis og i den efterfølgende jødiske og kristne udlægningshistorie, er det påfaldende, hvor lidt vigtige de egentlig er i Det Gamle Testamente som helhed. Abraham er ikke nogen prominent figur i Det Gamle Testamente. Noget tilsvarende kan man sige om temaet 'pagt' i forhold til Genesis' Abraham (og i øvrigt også om temaet 'tro'): I forhold til den samlede tekstmængde er det ikke et tema, hvis betydning for eftertiden svarer til dets numeriske forekomst. Ordet for 'pagt', $b^{e} r \hat{\imath} t$, optræder i fire narrative sammenhænge. Kun to gange er der tale om en pagt med Gud. Af disse nævner kap. 15 kun 'pagt' én gang og nærmest som en tilføjende forklaring på det gådefulde natteritual (v. 18), mens kap. 17, om omskærelsen, til gengæld bruger ordet hele 13 gange. I de to andre sammenhænge betegner $b^{e} r i \hat{t}$ politiske aftaler. I det på mange måder akavede kap. 14 kaldes to amoritter fra Hebron, og som der i øvrigt ikke fortælles noget om, for Abrahams 'pagtsfæller' (v. 13). I det meget klarere kap. 21 indgår Abraham en $b^{2} r_{\hat{\imath} t}$ med Abimelek, konge i Gerar, som regulerer Abrahams ophold på Abimeleks territorium. Det er altså i kap. 17, og reelt kun der, Abraham er en slags 'pagts-herre'. Kap. 17 er som bekendt den præsteskriftlige Genesis-kildes version af indledningen til kontakten mellem Gud og Abraham, og Præsteskriftet har jo sin egen $b^{e} r i t$-tematik, der begynder med Guds beskyttelse af Noa før syndfloden $(6,18)$ og regnbuen efter (kap. 9). Disse steder betyder $b^{e} r i ̂ t$ ifølge en plausibel, eksegetisk konsensus så meget som 'bindende, guddommeligt tilsagn'.27 I syndflodskonteksten synes der ikke at være tænkt på nogen udveksling overhovedet. I kap. 17 er forholdet måske lidt mere svævende. Nok er pagten her Guds suveræne tilsagn, der åbner for en fremtidig relation mellem Gud og den menneskelige part Abraham og hans husstand. Men den følges dog af påbuddet om omskærelse, og man overlades til sine egne spekulatio-

afsnit om "Abraham's Life-Style" (p. 36), som vil blive bekræftet og udvidet denne artikel. Mere konsensuspræget: Thomas Hieke, "Abraham" på www.wibilex.de (sidste redaktion januar 2005) (set 08-10-2010).

27. E. Kutsch, "ברית berît Verplichtung", Theologisches Handwörterbuch zum Alten Testament, red. Jenni Ernst \& Claus Westermann (München: Chr. Kaiser Verlag 1984), sp. 339-352: sp. 347-348. Jf. Claus Westermann, Genesis 12-36, BKAT I/ 2 (Neukirchen-Vluyn: Neukirchener Verlag 1981), $315 f$ f. ner om, hvad der ville være sket, hvis Abraham ikke havde taget imod pagten eller ikke ville gå ind på at markere den eller markere den på netop dén måde.

Den anden meget berømte tekst om Abraham er naturligvis kap. 22 om ofringen af Isak, som er åben for mange slags læsninger, ikke mindst i kraft af dens berømte ${ }^{28}$ ultra-lapidariske stil. Men tekstmaterialet er stadig langt fra udtømt. Og der er heri et tema, eller temakompleks, der ikke har fået tilstrækkelig opmærksomhed, og som just har med udveksling at gøre.

Gængse pagtanalyser interesserer sig for forholdet mellem pagt og ikke-pagt, altså den forskel det gør, om der består en pagt eller ej, og de forskelle, der består i en periode før og efter pagtsindgåelse (og evt. efter, at pagten er ophævet igen). Selvfølgelig vil man også være særligt interesseret i pagtens konkrete indhold - de stipulationer, regler og tabuer, gensidig anerkendelse, hjælp og støtte, som den indebærer. Der er derimod ikke så stor opmærksomhed over for den proces, der leder hen til pagtens indgåelse. For jordiske pagters vedkommende kan man tænke sig overvejelser og tidskrævende forhandlinger, sådan som man får en lille fornemmelse af $\mathrm{i}$ kap. 21 , den jordiske pagt mellem Abraham og Melkisedek. Men palaver forud for en pagt er vel ikke, hvad man normalt forbinder med den Abraham, hvis tavshed er berømt i kap. 22, og som også i Gen 15 slet og ret 'tror'. I andre fortællinger er Abraham imidlertid særdeles veltalende.

Jeg vil påstå, at denne kommunikative kompetence hænger sammen med et andet træk ved Abraham, som ofte er blevet sat i skyggen, og som måske, måske ikke, passer dårligt til billedet af troshelten Abraham - nemlig at Abraham først og sidst, frem for alt andet, er rig. Fortællingerne i Genesis gør, hvad de kan, på dette punkt, og det er ikke deres skyld, at Abraham for eftertiden primært er husket som pagtsherre og troshelt. Hvad teksterne lægger vægt på, er Abrahams velstand. Han vandrer ud fra Karan med Sara og Lot og "al den rigdom de havde samlet, og alle de folk, de havde skaffet sig i Karan" $(12,5)$. Opholdet i Egypten var særdeles givtigt ("han fik făr, køer og æsler, trælle og trælkvinder, æselhopper og kameler", 12,16). Adskillelsen fra Lot skyldes, at deres rigdomme er blevet så store, at de ikke kan være på samme territorium $(13,2.6)$. Abrahams velstand tillader, at han på stedet kan lade en kalv slagte for at beværte ham helt ubekendte besøgende $(18,17) .{ }^{29}$ Abimelek kompenserer ham for svie og

28. Jf. Erich Auerbachs klassiske analyse, "Die Narbe des Odysseus", Mimesis. Dar gestellte Wirklichkeit in der abendländischen Literatur (Bern 1946), 7-30.

29. Jf. kontrasten til den inverse scene i 1 Kong 17,12: 'gudsmanden' ('îsh 'elohîm) der besøger en ultra-fattig enke (til sammenhængen, jf. Hans J. Lundager Jensen, Den forterende ild (Århus: Aarhus Universitetsforlag 2000), 511-523. 
smerte med 1000 sekel sølv $(20,16)$. Det understreges, at Jahve havde velsignet Abraham på alle måder (24,1), og han dør, gammel og mæt af dage $(25,8)$.

\section{Gravpladsen hos hittitterne (Gen 23)}

Rigdommen indgår i fortællingen i kap. 23 om erhvervelsen af den hule med tilliggende ved Mamre, der skal blive til gravplads for Sara og ham selv. Dette kapitel tilskrives også Præsteskriftet. Men i modsætning til kap. 17, der er 'dogmatisk' præsteskriftteologi og ikke meget andet, har denne fortælling sin helt egen tematik, der ikke har noget religiøst, endsige 'teologisk', over sig. ${ }^{30}$ Abraham er interesseret i at komme ind på ejendomsmarkedet; men det er sælgers marked. Han henvender sig til de lokale, 'hittitter', som de kaldes, og melder sin interesse i beskedne vendinger: "Jeg er fremmed og tilflytter hos jer". Hvis Abraham nok gør sig lidt mindre betydningsfuld, end han egentlig er, giver de lokales svar ham ikke for lidt: "Hør på os, herre! Du er en Guds stormand iblandt os!" Abraham kan da bare tage et stykke jord; ingen vil nægte ham noget ... Abraham kaster sig da til jorden for dem og beder dem om at lægge et godt ord ind for ham over for Efron, der har lige det stykke land, han kunne tænke sig, og sige, at Abraham vil betale den fulde markedspris. Efron sidder allerede sammen med de lokale, og svarer: "Nej, hør på mig, herre!"; han vil da give ham marken gratis. Igen kaster Abraham sig ned på jorden og svarer, at det kan han ikke tage imod, og at han vil betale prisen. Da spørger Efron, hvad et stykke jord til 400 sekel skal betyde mellem de to? Og, som det hedder: "Abraham forstod Efron og afvejede den sum, Efron havde nævnt i hittitternes påhør, fire hundrede sekel gangbart sølv".

30. Generelt til Gen 23 som del af Præsteskriftet: Horst Seebass, Genesis II. Vätergeschichte II (23,1-36,43), (Neukirchen-Vluyn: Neukirchener 1999), 232. Eksegeterne er noget i vildrede med hensyn til sigtet med Gen 23. Hermann Gunkel forsøgte sig med en of forfteren ignoreret lokl hellig-hule: Geness, [1910] (Cötingen: Vanc Gotingen: Van arklaring har en vis eksegetisk popularitet: At Abraham skulle være model for den tilbagekomne fra eksilet: J. Alberto Soggin, Das Buch Genesis (Darmstadt: Wissenschaftliche Buchgesellschaft 1997), 320; R.N. Whybray, "Genesis", The Oxford Bible Commentary, red. John Barton \& John Muddiman (Oxford: Oxford University Press 2000), 38-66; Blenkinsopp, "Abraham as Paradigm in the Priestly History in Genesis", JBL 128 (2009), 225-241. Som alle allegoriserende Prestring tionalt-etnisk tematik, der ikke kan tages for givet i Det Gamle Testamente.
Eksegeter har diskuteret, om ikke Abraham i uansvarlig grad køber på toppen. ${ }^{31}$ Men hvis 400 sekel sølv faktisk var en ublu pris, vil fortællingen vise, at det er et greb i lommen for den rige Abraham. Dette er dog ikke nær så vigtigt som sætningen, at Abraham forstod Efron. Faktisk forstår de to hinanden udmærket, ligesom Abraham i det hele taget forstår hittitterne og de ham. Fortællingen handler altså om at forstå hinanden. Og behovet for at forstå hinanden melder sig netop i en handel, der foretages hen over etniske skel.

Det fremgår af denne fortælling, at Abraham har gangbar kapital til sin rådighed; han betaler ikke med okser og småkvæg, men med gangbart sølv. Økonomien i porten i Hebron er ikke en naturaliemen en pengeøkonomi. Abraham betaler ganske vist for brønden ved Be'ersheba med får og kør og syv lam (21,27-30). Men allerede i kap. 20 kompenseredes Abraham for affæren med Sara med 1000 seke sølv. I kap. 17 benævnes Abrahams slaver som dem, der er 'købt for sølv'. Og ifølge 13,2 er sølv og guld en del af Abrahams rigdom. Da Abraham formodentlig ikke skal forestilles også at være mineejer, er det nærliggende at antage, at pengerigdommen er kommet af gode handler, formodentlig med overskudskvæg.

\section{Handel med Gud (Gen 18)}

Kap. 23 er ganske vist noget så særligt som en 'præsteskriftlig' fortælling uden øjensynlig, religiøs pointe. Men at den ikke er enestående i alle henseender, viser den fortælling, Gen 18,32 der mest udførligt lader Abraham engagere sig med Jahve, nemlig i deres fortrolige samtale før Sodomas planlagte undergang. Abraham prøver som bekendt at forhindre byens ødelæggelse ved at appellere til Jahves retfærdighedssans. Den retoriske formulering er givetvis vigtig:

Vil du virkelig udrydde retfærdige sammen med uretfærdige? Måske er der halvtreds retfxrdige i byen. Vil du så virkelig udrydde dem og ikke tilgive stedet på grund af de halvtreds retfærdige, som er i den? Du kan umuligt handle sådan og slå retfærdige ihjel sammen med uretfærdige, så retfærdige og uretfærdige făr samme dom. Det kan du umuligt. Skulle han, der dømmer hele jorden, ikke øve ret?

Abrahams retoriske omstændelighed får replikken til at ligne et stykke prosa-lyrik, hvor leddenes parallelisme, kendt fra poesien, er er-

31. Blenkinsopp (2009), 239.

32. Ligheden er også set af Walter Brueggemann, Genesis (Atlanta: John Knox Press 1982), 195. 
stattet af en slags ekstrem simpel 'identisk parallelisme'. Da Jahve går med til det, fortsætter Abraham: "Nu vover jeg at tale til dig, Adonaj, skønt jeg kun er støv og akse", og foreslår, at 45 retfærdige vil være nok til at redde byen. Mere eller mindre retorisk indhyllet far Abraham Jahve talt ned til 10 retfærdige, og samtalen slutter: "Så gik Jahve"; det gør Abraham også.

Scenen er på nogle måder omvendt af den i Hebron: Abraham er konfronteret ikke med en etnisk fremmed, men med Gud; han vil ikke erhverve en ting, men forhindre en hændelse; han bliver ikke selv talt op, men forsøger at få en anden talt ned. Den ene gang er forhandlingen ganske vist en succes, den anden gang en fiasko, hvis man kan antage, at Abraham gerne ville have fortsat, hvis han havde turdet, indtil han nåede den ene retfærdige, Lot, som kunne have afværget katastrofen. ${ }^{33}$ Uanset hvad viser Abraham sig i begge tilfælde som en dygtig og smidig forhandler, der ved, hvordan man skal belægge sine ord.

Det kan se paradoksalt ud, at netop kvægavleren Abraham forsøger at redde en by, der muligvis skal forstås som indbegrebet af dekadence, med udøvelsen af den kunst, som traditionelt $i$ vestlig kultur tillægges netop bymennesket, nemlig høfligheden, der også kan betegnes med ord som 'urbanitet', 'civilisation', egenskaber der opøves i byen, urbs og civitas (via civis, 'borger'). Men Sodoma er netop en syndig by, ikke en by slet og ret. Intet berettiger til at se hittitternes Hebron som specielt fordærvet, tværtimod (og Abraham har intet imod at besidde et gravsted i dens nærhed). Lot, der selv er blevet byboer, er heller ikke fordærvet, men udviser en gæstfrihed, der ikke er ringere end den, den rurale Abraham demonstrerer i kap. 18. Til gengæld er det åbenbart ikke kun i den vestlige kultur, sammenhængen mellem høflighed og byliv er hævdet, som det fremgår af Merete Reinholdts artikel "Nøglen til den høflige by" om Tokio i Weekendavisen $\left(36\right.$; 2010). ${ }^{34}$ Her peges der på tre steder, hvor japanerne lærer "kompetencer for civil høflighed": markedspladsen, steder for udøvende kunstarter og helligstederne. Med disse "koder eller regler for god opførsel evner man at behandle alle ens og gøre byen til et godt sted at være". Der henvises i sammenhængen også til Jean Baudrillards overvejelser over "spillets regler og lovens orden" og den saglige lighed mellem helligstedet og markedspladsen; hvor man er færdig,

33. Også Paul Beauchamp undrer sig, med andre, over, hvorfor Abraham ikke fortsætter ned til den ene, men kan ikke foreslå andet svar, end at ét retfærdigt menneske ikke er nok, fordi mennesket ikke er skabt til at være ene, altså at retfærdighed altid er social (Cinquante portraits bibliques (Paris: Seuil 2000), 27.

34. På baggrund af Anni Greve, Sanctuaries of the City: Lessons from Tokyo (London: hvis man snyder (som allerede Buddenbrooks i øvrigt viste). I forhold til en gammeltestamentlig sammenhæng lyder dette rigtigt. For er der ét sted i verden, hvor ekstrem højlighed er en betingelse for overlevelse, er det netop i omgangen med det guddommelige og med hellige genstande, hvor én forkert bevægelse jo kan koste en livet (2 Sam 6,6f.), og hvor selv ypperstepræsten må iagttage den dybeste tavshed.

Men denne præstelige verden er netop ikke Abrahams virkelighed. Han er en flittig alterbygger, og han anråber Jahves navn. Men han går ikke i tempel. Ganske vist er der i sagens natur ikke, og kan ikke være, noget Jahvetempel. Men denne pointe er triviel. Det er mindre trivielt, at intet tyder på, at Abraham skulle have savnet templet. Hvad han excellerer i, er ikke korrekte ofringer eller overholdelse af renheds- og spiseregler. Han lever et rigt liv og dør i høj alder, mæt af dage, en ideel død, som kun få kunne håbe på. Dette liv lod sig åbenbart, ifølge forfatterne, leve uden tempel, uden præsteskab, uden renhedsregler.

\section{Kvindehandel i familien (Gen 24)}

Den tredje og sidste fortælling, som vi her skal se på, er Gen 24, hvor Abraham selv er i baggrunden, og det er hans major domus, ældstetrællen $\mathrm{i}$ hans hus, der på hans vegne foretager en rejse tilbage til slægten i Nordsyrien for at hente en passende hustru til sønnen Isak. At Jahve havde velsignet Abraham på alle måder (v. 1), vil i sammenhængen her i hvert fald sige, at han har kapital nok til at afsende en veludrustet kamelkaravane. Brøndscenen, hvor Rebekka spontant vander trællens kameler, er nok en idyl, men egentlig ikke en landlig idyl, for målet for rejsen er en by, og alt er passende urbant i denne skønne, om end ikke hårrejsende spændende, fortælling. Det er ikke så lidt, trællen må punge ud med for Rebekka. Næseringen (af guld; vægt: én beka) og de to armringe (af guld; vægt: to sekel) er tilsyneladende kun for at bryde isen. Men det giver god mening, at trællen på vegne af kvægholderen Abraham medbringer guld. Med en levevis, der indbefatter transmigration, kan overskud dårligt investeres i fx byggeri. Mere nærliggende er det at opbygge en kapital af ædelmetal, hvor værdien er maksimal i forhold til vægt og omfang. Har man først guldet, er det lige så nærliggende at have det i form af smykker; og da smykker skal være et sted, kan det passende være på ens kvinder. Da trællen sidder over for de egentlige partnere, der er Rebekkas bror Laban og hendes mor, holder han sig da ikke tilbage med at forklare, hvor rig Abraham egentlig er: "Jahve har velsignet min herre, 
og han er blevet meget velstående. Han har givet ham får og køer, sølv og guld, trælle og trælkvinder, kameler og æsler" (v. 35).

$\mathrm{Da}$ forhandlingen kommer til sagen, er Labans udspil tilsyneladende meget direkte: "Dette kommer fra Jahve. Vi kan intet sige til det! Dér har du Rebekka, tag hende og rejs hjem (...)". Dette udspil er det modsatte af en formentlig ret udbredt nordisk forestilling om, at rigtig handel består $i$ aggressivt at tale varens værdi, og dermed sælgerens moralske status, ned. Men Laban og Abrahams træl er ikke danske turister i en mellemøstlig souk. Trællen tager ikke Laban på ordet for hastigt at drage af sted med det overraskende gode tilbud. Tværtimod finder han først nu smykkerne af guld og sølv samt klæderne til Rebekka frem og også de "kostbare gaver" til Laban og hans og Rebekkas mor. Trællen ved tydeligvis, hvordan man forhandler i dette scenarie, der adskiller sig fra de to andre ved at foregå inden for familien, men som ellers er lige så købmandsagtigt som Abrahams køb af marken ved Hebron. Gangen i forhandlingen er den samme: Sælgeren indleder med at storslået at tilbyde den efterstræbte vare gratis, og dét er signalet til, at køberen betaler en lige så storslået pris. For de 'gaver', trællen her giver, er naturligvis betaling, og i hvert fald her er der ikke sådan noget som a pure gift.

Men det sker også noget andet og mere. I og med handelen med materielle værdier foregår, hvad man kan kalde en deutero-handel (eller meta-handel). Forholdet kan sammenlignes med, at der i og med ethvert udsagn i et givet sprog også og samtidig sker en bekræftelse af dette sprog som en fælles, kommunikativ kode, der forbinder de kommunikerende partnere henover deres individualiteter og forskelligheder. I og med handelsaktens replikker og gestik bekræfter begge parter, at de kender og opretholder den gode handels moral og retorik. Trællen og familien gør begge en god handel, ligesom Abraham og hittitterne, for ting skifter ejermænd til den pris, begge parter er tilfredse med. 'Markedet virker', og det sker på den urbane måde, der er markedets forudsætning.

Jeg foreslår altså i Abraham at se spor efter en købmandsmoral, der ikke går ud på at berige sig på andres bekostning, men på at effektuere den gode handel og bekræfte, at man er civiliserede mennesker, der ikke bare tager og giver, men som giver sig den tid og overholder de koder og regler, der hører sig til, når ordentlige folk har med hinanden at gøre. Partnerne på markedspladsen tilstræber ikke intimt fællesskab. De er tilfredse med, at varerne har skiftet hænder på den rette måde, og at de kan afbryde kontakten igen. Markedspladsen er for dem en verden, men ikke hele verden. Der er også familien og de andre i ens egen by, som man kender og hører sammen med på en an- den måde end de kortvarige forbindelser, der opstår i handelens korte, intense møder.

Købmandens religion?

Når Genesis' Abraham er en kvægfyrste i stor stil, skyldes det sikkert flere forhold. For det første er Abrahams familie og husstand kun én, og den kan under alle omstændigheder bedre forestilles som en teltenhed end som et hus i en by eller landsby, tilmed i en by med folk af anden etnisk identitet. Men der kan tænkes flere andre grunde. Der kan heri ligge en underforstået afstand til Jerusalem i den persiske tid, hvortil det under alle omstændigheder er mest nærliggende at datere fortællingen. Unægtelig ved vi meget lidt om Jerusalem i denne periode. ${ }^{35}$ Men det eneste indtryk, vi får fra de få tekster, der faktisk siger noget om dette, navnlig fra Ezras og Nehemias' bøger, er et triumferende hotbed af religiøs fanatisme, hvor det betragtes som helt rimeligt, at en voksen mand hysterisk flænser sit tøj og river sig i hår og skæg, hvis han ikke kan få sin vilje (Ezra 9,3). Lige netop sådan er Abraham ikke: Lot kan vælge sin del af landet først; Sara vil have en søn via sin trælkvinde - javel. Sara jager så trælkvinden væk - lad gå med det; Jahve siger, at Abraham skal bryde op fra Karan og tage til et land, som han vil vise ham? - godt, Abraham gør det; Gud vil have Abraham til at ofre sin søn? - ja, hvad kan han så stille op? Abraham prøver at se, hvor langt han kan få Jahve til at gå ned; til ti? - vel, det var så det. Han kan dagen efter kun stå i det fjerne og se røgsøjlen over det, der engang var Sodoma; man kan ikke bebrejde Abraham, at han ikke gjorde, hvad han kunne.

Jeg vil altså foreslå at se Abraham som en emblematisk repræsentant for det borgerlige og det moderate. Han kan begå sig over for hittitterne i byen, Jahve (i himlen?) og kvinderne inde i teltet, fordi han ved, hvor langt han kan gå, og fordi han anerkender sine modparters domæner og deres kompetencer i de koder og regler, der medierer interaktionen og udvekslingen. Fortællingerne er således også en implicit kritik af den militante deuteronomisme, som gammeltestamentlige forskere alt for ofte tager som selve indbegrebet af gammeltestamentlig religiøsitet - som om alt i Det Gamle Testamente var nationalisme, væltede afgudsaltre og etnisk udrensning. ${ }^{36}$ Abra-

35. Der er dog grund til at antage, at der har været en intakt kult, også under eksilet, jf. Peter R. Ackroyd, Exile and Restoration. A Study of Hebrew Thought of the Sixth Century B.C. (Philadelphia: The Westminster Press 1968), 25-29.

36. I sit portræt af Abraham hæfter Beauchamp (2000), 25 sig med rette ved Abrahams philoxenia i Gen 18 
ham bygger altre; men han river ikke andres ned; og han er ikke så fintfølende, eller hans religion er ikke så skrøbelig, at han ikke kan begrave sin kone, og sig selv, i nærheden af en hittitisk by, hvor de lokale må antages også at have haft et tempel eller i det mindste en beskeden open-air-sanctuary til deres lokale guddom eller guddomme.

For det tredje er der god grund til at forbinde Abrahams status som rig kvægavler og karavaneudruster med nærheden til Levantens og Arabiens handelsveje. ${ }^{37}$ I kap. 24 er Abraham handelsmand i den store stil, der financierer en karavane op til Karan. Abraham bliver som bekendt gjort til stamfader til ismaelitterne via trælkvinden Hagar og til en lang række andre arabiske stammer via sit andet ægteskab med Ketura, der jo betyder 'røgelse' (Gen 25,1) og tilsyneladende med atter andre, navnløse, hustruer $(25,5)$. Ismaelitterne dukker op i Gen (kap. 37), netop som transregionale handelsmænd, der handler med aromater og andre nyttige stoffer for mumieproduktion, som der er et marked for i Egypten, og som de har købt i Gilead - samt slaver. Når Abraham, selv slaveejer, er blevet gjort til stamfader til netop araberne, kan det skyldes, at disse i Palæstina primært kendtes som handelsfolk, der tjente godt på den lukrative handel med aromastoffer og andre luksusvarer fra Jemen. ${ }^{38}$ Araberne var altså rige, som Abraham er rig, og som Salomo i øvrigt bliver rig med de såkaldte Tarshish-skibe, der efter deres eksotiske varer at dømmeguld, sølv, elfenben, aber, bavianer (1 Kong 10,22) - skal forestilles at drive handel på Arabien eller på den østafrikanske kyst.

I virkelighedens verden kunne mange handelsfolk utvivlsomt godt tjene lidt ekstra ved en improviseret plyndring (jf. Job 1,15). Men generelt fungerer fjernhandel kun med sikrede handelsveje. Handel er en anden måde at fordele goder på end krig, og Salomo er logisk nok den store fredskonge. Krig kan være nødvendig for at forsvare et territorium, og selv Abraham kan gøres til krigsherre, som det sker i kap. 14 (og som bryder med alt andet, der siges om han i Genesis). Samlet set er Abraham imidlertid lige så lidt kriger, som han er præst, deuteronomistisk ideolog, profet, bonde eller skriver. Abraham er meget snarere en tidlig kapitalist, ${ }^{39}$ en rigmand, der som Salomo ønsker fred omkring sig, som forstår betydningen af at bøje sig efter andres kulturer, at kunne leve $i$ et land med en etnisk fremmed ma-

37. Som det er sket tidligere i forskningen (W.F. Albright; C.H. Gordon); deres teorier er blevet afvist, fordi de var for bundet til uplausible folkevandringsteorier; se Westermann (1981), 78.

38. Til arabere (og fønikere) som datidens krøsusser, set fra Palæstina, se Knauf (1994), 151.

39. Til tidlig kapitaldannelse, jf. Knauf (1994), 45. joritet og ramme den tone, der bekræfter dem og ham $i$, at man vel er civiliserede mennesker, der forstår at gøre en ordentlig handel.

Religion flekteres uundgåeligt af socialitet. Agerbrugere, administratorer, præster, mænd og kvinder, osv. har duundgåeligt/forskellige the hve 4 prioriteringer i deres liv, herunder også i deres religiøse liv. Hvad der dign's er essentielt og af uopgivelig betydning for den ene gruppe, kan være irrelevant eller direkte skadeligt for den anden. Religioner i samfund af blot en nogenlunde udviklet arbejdsdeling og funktionel kompleksitet vil fundgåeligt udvikle også en 'religionsintern pluralisme'.40 Man kan blot tænke på de helt forskellige prioriteringer i hhv. det præsteskriftlige og det deuteronomiske tekstkorpus i Pentateuken og i visdomsbøgerne.

Har købmænd defineret en egen stand, og har den haft sin særlige religiøse prægning? Hvis der har eksisteret noget i retning af en særlig købmandsreligiøsitet, kunne den have omfattet forestillingen om en personlig gud som den, der 'vandrer med', den der beskytter på rejse til fremmede områder uden for den umiddelbare sociale sikkerhed, der består i ens familie og ens by. Den individuelle fromhed har netop den guddommelige rejseven som én af sine stabile figurer. Det kan være Jahve selv, der vil gå med Jakob og beskytte ham, til han kommer hjem (Gen 28,15.20f.). Men det kan også, givetvis i sene tekster, være en skytsengel, som Rafael i Tobits Bog, hvis funktion alene er at beskytte Tobias på hans iranske rejse, og som tager afsked, da Tobias er velbeholden tilbage i Nineve (Tob 12). Gen 24 ligger imellem disse to muligheder. På den ene side er det Abrahams Gud selv, trællen beder til, da han står ved brønden og venter på, at den rette kvinde vil dukke op (v. 12.27). På den anden side forventer Abraham, at 'Jahve, himlens gud', vil sende sin engel foran trællen på rejsen, så den kan blive en succes (v. 7.40).

Man kan gætte på, at købmænd, uden for deres hjemby, gerne ville have steder på deres faste ruter, hvor de kunne udføre de ritualer eller fremsige de bønner, hvis former under alle omstændigheder faldt ind under en nærorientalsk 'common theology', snarere end en bestemt religion. En nærliggende mulighed ville være altre i forbindelse med større kultkomplekser eller templer de steder, hvor de havde deres handelskontakter, som markedssteder eller handelsgader. ${ }^{41} \mathrm{Og}$ man

40. Rainer Albertz, Religionsgeschichte Israels (Göttingen: Vandenhoeck \& Ruprecht 1992), 144-150.

41. I middelalderen var det normalt for fremmede købmænd at integrere deres særlige helgener i de byer, hvori de opholdt sig i kortere eller længere tid, $f x$ ved at lade altre få hjemsted i eksisterende kirker; således havde købmændene fra Greifswald i senmiddelalderen opstillet (givetvis imod betaling) et Maria-alter i Niko- 
kan formode, at købmænd ville have det bedst med en religionsform eller en gudsopfattelse, der var tilstrækkelig distinkt til overhovedet at besidde en identitet, men som ikke overbetonede forskelle og konflikter, og som var åben over for identifikationer med andre gudsnavne - som $\mathrm{fx}$ at ens guddom (i al fredsommelighed) var 'himlens gud' (Gen 24,7).

\section{Rewritten Abraham}

Den Abraham, der ikke er trosherre eller national stamfader, kan derfor ses som typen på en handels- og kapitalorienteret religionstype, der agerer på grænsen mellem det egne og det fremmede, og som evner at bevare sin identitet uden at blive fanget ind af en voldelig rivalisering med det anderledes, fordi dette anderledes (de eksotiske varer) er nødvendigt for, at ens egen eksistens (som købmand) fortsat kan bestå. For denne types mennesker kommer rigdommen fra udveksling af varer henover nationale, politiske og religiøse grænser, og derfor er det, der forener én med de fremmede, mindst lige så vigtigt som det, der skiller.

Men er der en måde at 'verificere' denne udlægning på? Jeg vil afslutningsvis foreslå en art negativt bevis ved at gå til udlægningshistorien. Normalt betragtes og omtales denne i positive kategorier: Det bibelske udgangspunkt afføder nye og rigere billeder og fortællinger. Men man kan også betragte den som en underforstået kritik af de bibelske tekster, om ikke for at være ukorrekte så for at være irrelevante. Hvis den selekterer kraftigt, som i den tradition fra Paulus og til nutiden, der i Abraham kun ser stamfaderen, troshelten og pagtsherren, vil det ikke være unfair heri at se en marginalisering af de øvrige Abraham-fortællinger og -billeder som uessentielle og overflødige. Abraham, den velhavende, købmanden, kapitalbesidderen, den retorisk virtuose forhandler, er altså blevet fraselekteret som irrelevant den teologiske tradition. Formentlig var det den handels- og kapitalismekritiske linje, der er så tydelig hos Ezekiel, som kom til at dominere eftertiden. Men man kan også og endnu tydeligere se den implicitte kritik af det bibelske materiale dér, hvor denne bliver genstand

lajkirken i København: Ellen Jørgensen, Helgendyrkelse i Danmark (København: Hagerup 1909), 33. Hvis der er noget realistisk i, at en Abraham skulle kunne opstille altre for sin egen skytsguddom i Sikem, Betel og Mamre/Hebron (Gen $12,7-8 ; 13,18)$ og plante en (formentlig 'hellig') tamarisk i Be'ersheba $(21,33)$, kan det så være sket på anden måde, end at han har fået lov til at etablere en religiøs udpost i et allerede eksisterende kultisk, og i sagens natur religiøst 'tolerant' miljø? for kreativ nyskrivning, altså som såkaldt 'rewritten Bible'. Et af de tidligste eksempler på det må være Jubilæerbogens Abraham. I den meget lange og stærkt kreative skildring introduceres han først og fremmest som den, der bryder med dyrkelse af gudebilleder (Jub 11,16-17). Han har også særlige ravne-apotropæiske evner og introducerer i den forbindelse en forbedret plovteknologi i Sydmesopotamien (11,18-24), ligesom han erkender astronomiens irrelevans $(12,16-18)$. Intet af dette forekommer i Genesis, men det er åbenlyst meget vigtige emner for Jubilæerbogens forfatter. Når de ikke er blevet sagt $\mathrm{i}$ Genesis, har han måtte gøre det. For Jubilæerbogen er Abraham først og fremmest den, der afviser afgudsdyrkelsen. Mens Jubilæerbogens Abraham endnu bor med sin familie i Kaldæa, står han op om natten og brænder det lokale 'afgudshus' af. Hans egen broder Haran brænder inde, da han prøver at redde sit gudebillede. Abraham som mordbrænder? Ikke i Genesis. 